Rev. salud pública. 14 (2): 260-270, 2012

\title{
The cost-effectiveness of open or thoracoscopic thymectomy compared to medical treatment in managing Myasthenia gravis without thymomas
}

\section{Costo efectividad de timectomía abierta y toracoscópica frente al tratamiento médico, en el manejo de Miastenia gravis sin timoma}

\author{
Liliana A. Chicaiza-Becerra ${ }^{1}$, Mario Garcia-Molina², Oscar Gamboa ${ }^{3}$ and
} Carlos Castañeda-Orjuela ${ }^{4}$

1 Facultad de Ciencias Económicas, Universidad Nacional de Colombia, Bogotá, Colombia. lachicaizab@unal.edu.co

2 Facultad de Ciencias Económicas, Universidad Nacional de Colombia, Bogotá, Colombia mgarciamo@unal.edu.co

3 Instituto Nacional de Cancerología, Bogotá, Colombia Gamboa Oscar<oa_gamboa@yahoo.es

4 Ciencias Económicas, Universidad Nacional de Colombia, carloscastanedao@gmail.com

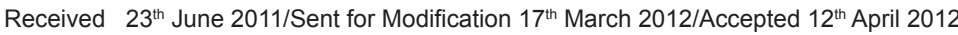

\section{ABSTRACT}

Objective Assessing the cost-effectiveness of open or thoracoscopic thymectomy compared to medical therapy in managing myasthenia gravis not associated with thymoma.

Methods A Markov model was designed for evaluating three strategies' costeffectiveness. Transition probabilities were taken from the pertinent literature; the costs were estimated from official tariff manuals. Incremental cost-effectiveness ratios were estimated and probabilistic and deterministic sensitivity analysis was used for clinical variables, costs and the model's assumptions.

Results Thoracoscopic thymectomy was the most effective and least costly strategy and dominated the other two alternatives. The cost per life year gained was Col \$ 1129531 without discount and Col \$ 805179 with discount. Univariate sensitivity analysis showed that the main variables affecting the results were the effects' discount rate, the cost of a myasthenic crisis and the probability of complete remission. Thoracoscopy thymectomy was the most cost-effective strategy for different thresholds of willingness to pay in probabilistic analysis.

Conclusions Thoracoscopic thymectomy is a cost-effective strategy in the treatment of MG without thymoma.

Key Words: Myasthenia gravis, therapeutics, thymectomy, cost-benefit analysis, Colombia (source: $\mathrm{MeSH}, \mathrm{NLM}$ ). 


\section{RESUMEN}

Objetivo Evaluar la costo efectividad de las timectomía abierta y toracoscópica frente a la terapia médica en el manejo de miastenia gravis sin timoma.

Método Se construyó un modelo de Markov para evaluar la costo efectividad de las 3 estrategias. Las probabilidades de transición se obtuvieron de la literatura. Los costos se estimaron a partir de las tarifas oficiales. Se calculó la costo-efectividad incremental. Se realizaron análisis de sensibilidad probabilísticos y determinísticos para las variables clínicas, los costos supuestos del modelo.

Resultados La timectomía toracoscópica es la estrategia más efectiva y menos costosa, y domina a las otras dos alternativas. El costo por año de vida ganado fue de \$ 1129531 y \$ 805179 pesos colombianos, con y sin descuento. El análisis de sensibilidad univariado mostró que las principales variables que afectan los resultados son la tasa de descuento, el costo de una crisis miasténica y la probabilidad de remisión completa. En el análisis de sensibilidad probabilístico, la timectomía toracoscópica es la estrategia costo-efectiva para los diferentes umbrales de disponibilidad a pagar.

Conclusiones La timectomía toracoscópica es una estrategia costo-efectiva en el tratamiento de miastenia gravis sin timoma.

Palabras Clave: Miastenia Gravis, terapéutica, timectomía, análisis costobeneficio, Colombia (fuente: DeCS, BIREME).

M yasthenia gravis (MG) is a neuromuscular transmission autoimmune disorder which is usually mediated by specific antibodies against the human nicotinic acetylcholine receptor (12). MG treatment includes cholinesterase inhibitors, corticosteroids, other immuno-suppressants or surgery. Thymectomy is one of the most commonly used treatments. However, a recent review found no conclusive benefit of thymectomy in MG patients without thymoma and only recommended it as an option for increasing the likelihood of remission or improvement (3).

Surgery effectiveness depends on complete excision of the thymus; there are two types of thymectomy: open (sternotomy) and thoracoscopy, the latter having been shown to have similar efficacy to the open operation with fewer adverse effects and better cosmetic results (4).

Treatment involves differences in cost given by their effectiveness in achieving complete disease remission, adverse events and hospital stay. Given the uncertainty about the effectiveness and costs of different MG management options, this study was aimed at evaluating the costeffectiveness of open or thoracoscopic thymectomy compared to medical therapy in the management of MG without thymoma. 


\section{METHODOLOGY}

A Markov model was constructed in which the following strategies were evaluated: medical treatment, open thymectomy and thoracoscopic thymectomy. Effectiveness was measured in terms of life years gained (LYG); a $3 \%$ discount rate was applied to costs and effects.

\section{Markov model}

The model starts with patients in the "without complete remission" state who are then treated with some of the strategies being evaluated; after initial treatment, they can move annually to the following states: complete remission, myasthenic crisis, death, or stay in the "without complete remission" state (Figure 1).

Figure 1. Markov model of MG treatment

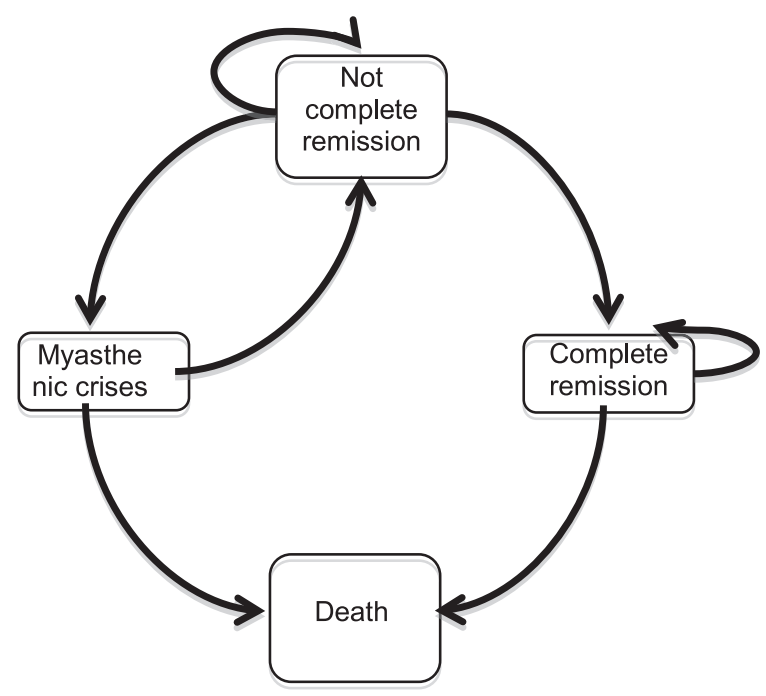

Arrows indicate possible transitions between different states. Complete remission: patient was asymptomatic and without medication; myasthenic crisis: respiratory failure due to general or upper-respiratory-muscles paralysis requiring ventilatory support.

The following assumptions were made:

1) A start was made with a cohort of 22 -year-old patients and simulations ran until they were 76 ; 
2) Myasthenic crisis only occurred in patients without complete remission; 3) After reaching complete remission, a patient did not return to "without complete remission"; and

4) Adverse thymectomy events included in the model were: surgical wound infection, mediastinitis, mediastinal haematoma and presence of pericardial exudate.

Clinical data

A systematic review was made of the pertinent literature from which data was extracted regarding the effectiveness and risk of management strategy complications (5-19). Following Miller's recommendations (20), the probability of achieving complete remission, presenting myasthenic crisis or dying from the disease or other causes was calculated; Table 1 shows the data used in the model and sensitivity analysis ranges.

Cost data

Third payer perspective was used, including direct costs related to treatment, hospitalisation cost (in a room or ICU) and complications' management (Table 2). Costs were calculated according to the official tariff rates manual (SOAT). Monetary units were expressed in Colombian pesos (2008).

\section{Analysis}

The incremental cost effectiveness ratios (ICER) were estimated, efficiency curves built and univariate sensitivity analysis conducted for model costs, effects and assumptions. A probabilistic sensitivity analysis was made and confidence regions and acceptability curves constructed.

\section{RESULTS}

Thoracoscopic thymectomy was the most effective and least costly of the strategies and dominated the other two alternatives while medical treatment strategy was the more expensive and least effective alternative. LYG for thoracoscopic thymectomy with discount was 23.46 and 42.31 without it, for a cost of Col \$1,129,531 per LYG with no discount and Col \$ 805,179 with discount (Table 3). 


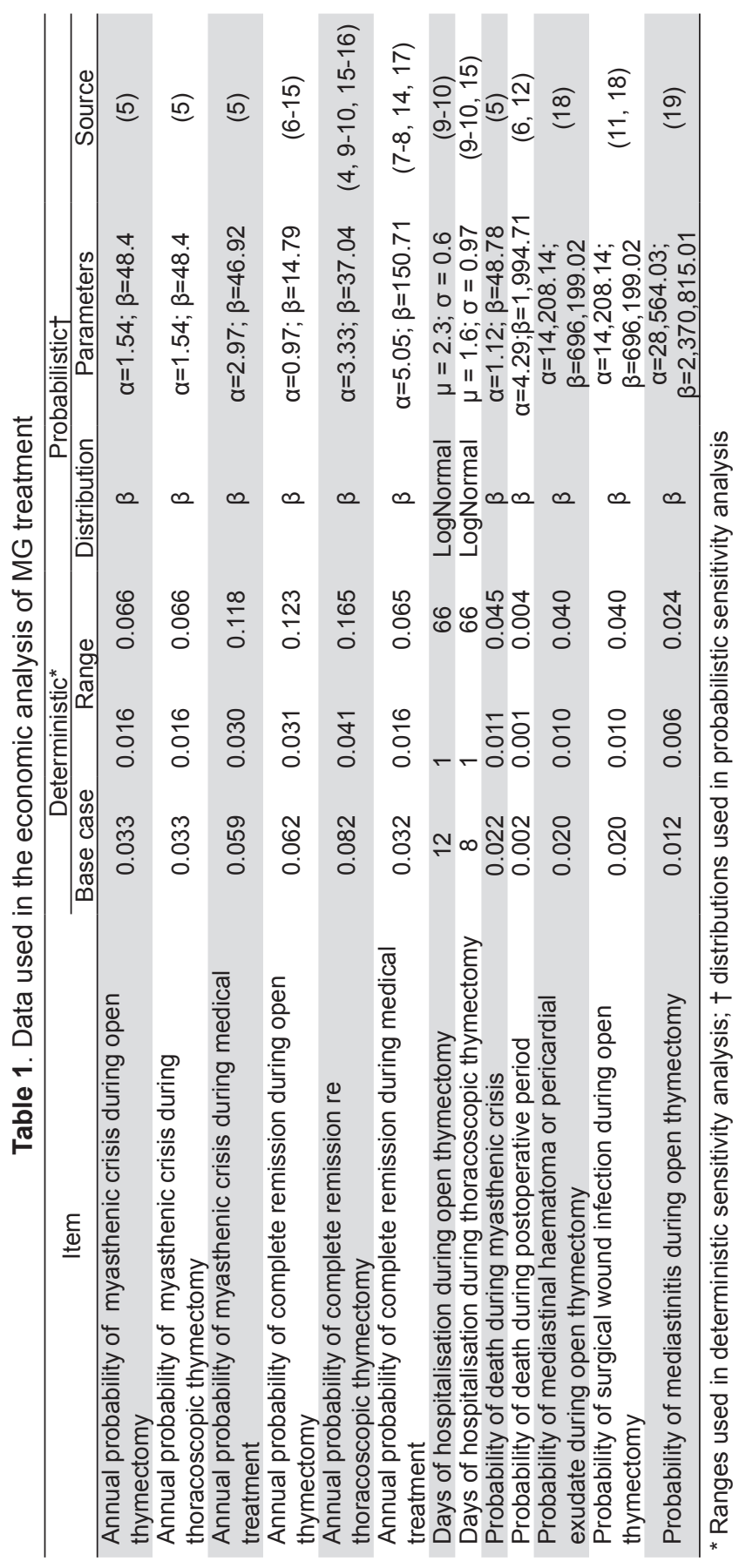




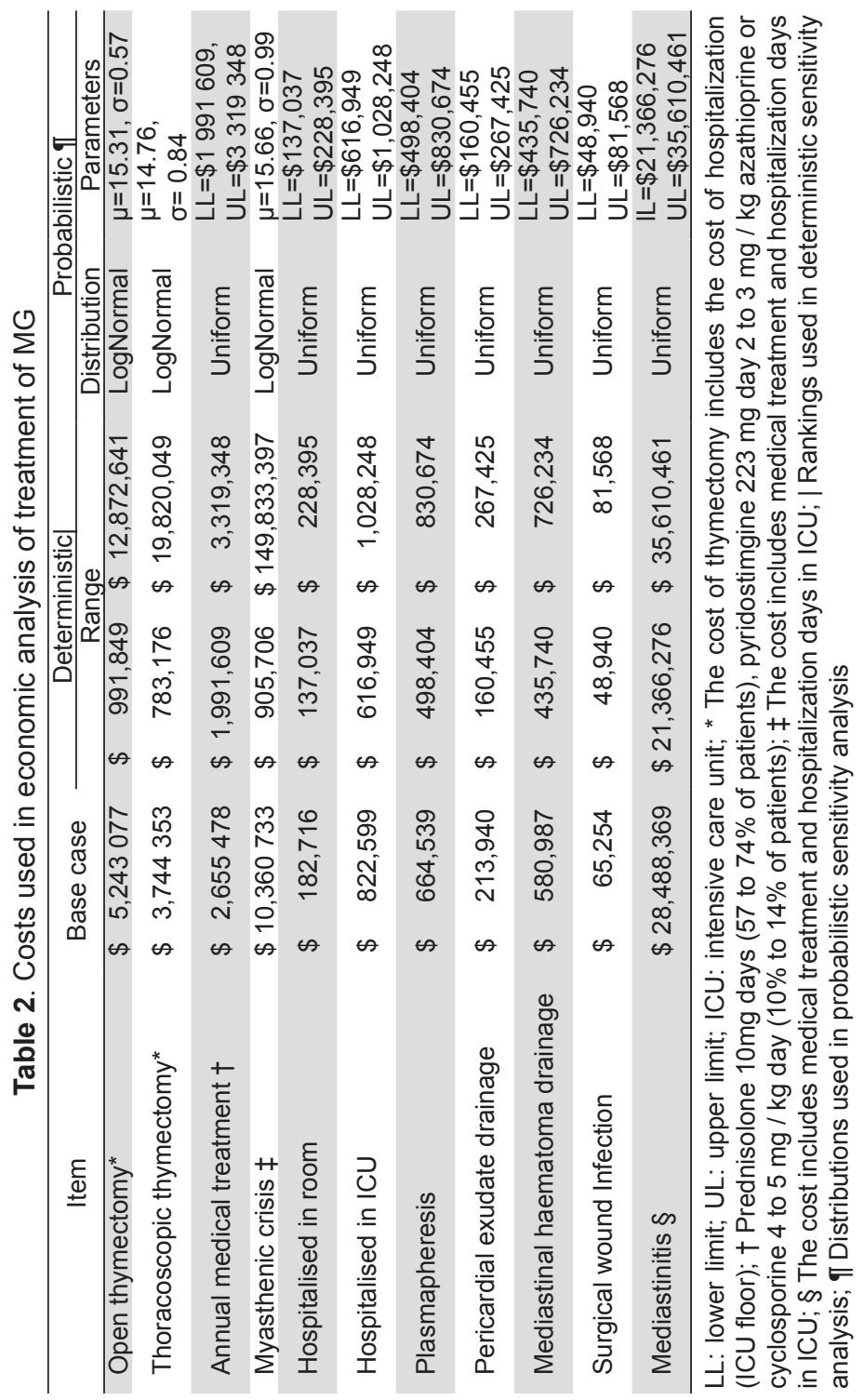




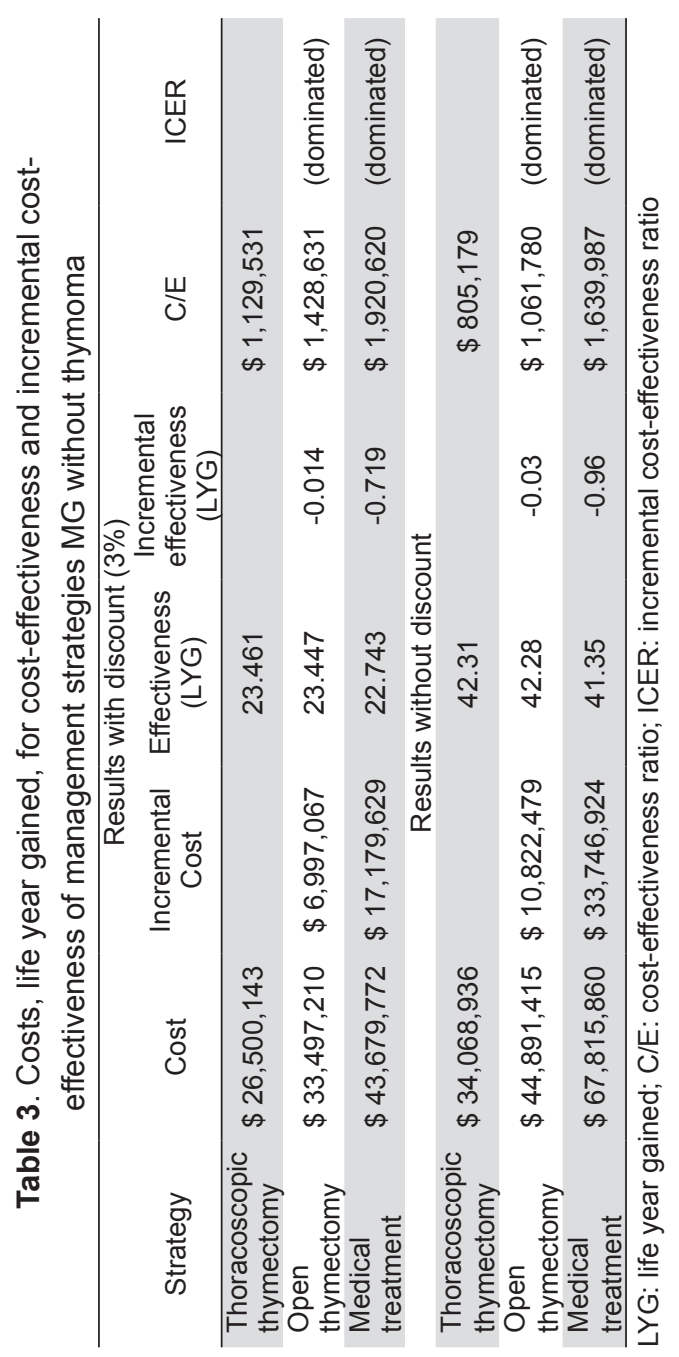


Univariate sensitivity analysis

Figure 2 gives the thoracoscopic thymectomy tornado diagram showing that the main variables affecting the results were the effects' discount rate, the cost of a myasthenic crisis and the likelihood of complete remission. Thoracoscopic thymectomy was no longer the most cost-effective strategy if days of hospitalisation after the procedure were greater than 27 days, the cost of surgery was greater than Col $\$ 7,800,000$ or annual probability of achieving complete remission was less than $5.5 \%$; open thymectomy was the most cost-effective strategy for these cases.

Probabilistic sensitivity analysis

Figure 3 shows the confidence region regarding the level of effectiveness of thoracoscopic compared to open thymectomy. Thoracoscopic thymectomy was cost effective for $70.4 \%$ of the 10,000 simulations. This corresponded to the area under the diagonal representing willingness to pay per unit of effectiveness $(\$ 7,600,000$ per LYG). This threshold corresponded to the Colombian 2008 per capita GDP.

Thoracoscopic thymectomy was cost effective for a wide range of willingness to pay from zero to Col $\$ 24,000,000$ per LYG on the acceptability curve (not shown).

\section{DISCUSSION}

There have been no previous economic evaluations comparing these techniques in the treatment of MG not associated with thymoma. Only one study has been reported assessing the use of cyclosporin A compared to a combination of corticosteroid and immunotherapy in MG patients (21). As no consensus has been reached on the use of surgical techniques in treating thymoma-associated MG, two surgical thymectomy techniques were assessed and compared to the alternative drug used for treating these patients.

The present analysis showed that the thoracoscopic thymectomy strategy was cost-effective in treating $\mathrm{MG}$ without thymoma and remained so up to surgery costs representing $\$ 7,800,000$ per procedure; thymectomy by sternotomy (open thymectomy) became cost-effective at higher costs. This comparison included conventional medical treatment costing $\$ 1,920,620$ per LYG. 
Figure 2. Tornado diagram of a thoracoscopic thymectomy

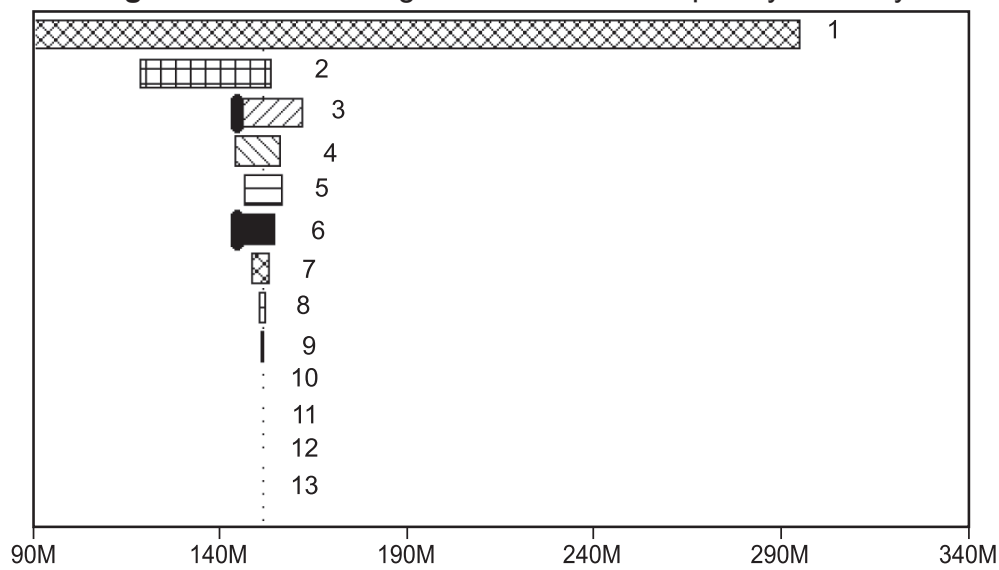

1 Effects discount rate: 0 to $0.06 ; 2$ Cost of myasthenic crisis: $\$ 905,705.99$ to $\$ 149,833,397.4 ; 3$ Probability of full remission thoracoscopic; thymectomy: 0.041212566 to 0.164850265 ; 4 Costs discount rate: 0 to 0.06 ; 5 Annual medical treatment cost: $\$ 1,991,608.84$ to $3,319,348.067 ; 6$ Cost of thoracoscopic thymectomy: $\$ 783,175.84$ to $\$ 19,820,048.85$; 7 Probability of myasthenic crisis thoracoscopic thymectomy: 0.015394701 to 0.061578804 ; 8 Probability of death from myasthenic crisis: 0.011235955 to 0.04494382 ; 9 Probability of post-operation death: 0.001072961 to $0.004291845 ; 10$ Plasmapheresis cost: $\$ 498,404.43$ to $\$ 830,674.05$; 11 Floor hospitalization cost: $\$ 137,036.99$ to $\$ 228,394.99$; 12 ICU hospitalisation cost: $\$ 616,949.1$ to $\$ 1,028,248.5$; 13 Hospitalization days for thoracoscopic thymectomy: 1 to 66

Figure 3. Confidence region regarding the level of

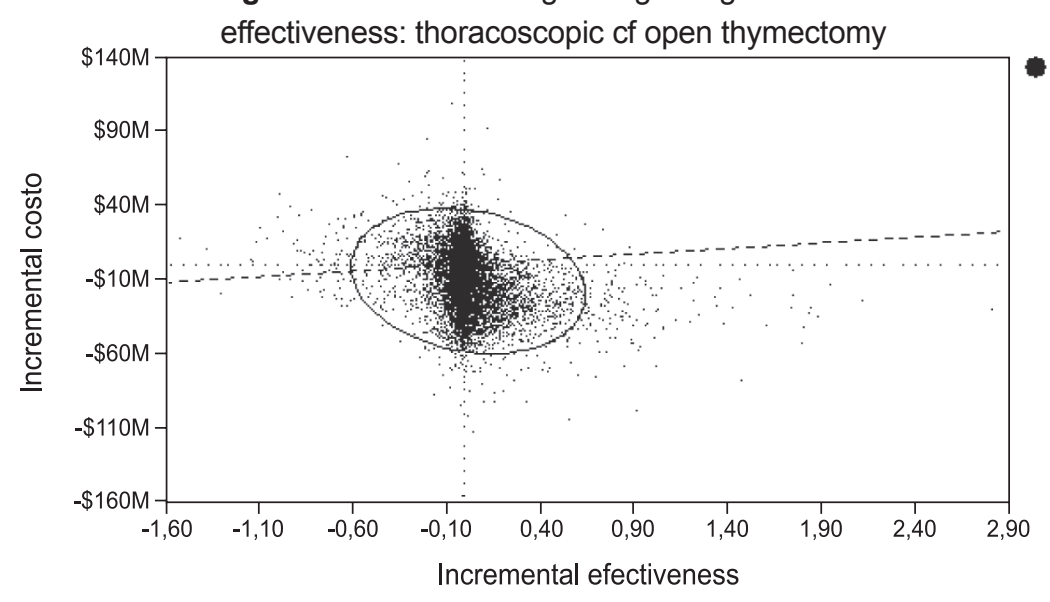


A major limitation of this article is that the effectiveness data used for each alternative was obtained from case series studies involving few participants and not from randomized trials directly comparing assessment strategies; thus, if the effectiveness of the therapies considered were significantly different from those used here, then the results could change. Higher quality studies should thus be carried out, particularly randomized controlled trials, to gain more certainty as to the effectiveness of each intervention. It should be noted that this analysis did not consider the use of the latest techniques in performing thymectomy, such as extended transcervical thymectomy (22-23) which has shown benefits in reducing post-operation complications and post-surgery recovery time, but apparently involves no differences re effectiveness (24)

Acknowledgements: This study was financed by the Universidad Nacional de Colombia within the framework of a project entitled, "Evaluating Teaching Hospital Clinical Practice Guidelines."

\section{REFERENCES}

1. Schluep M, Willcox N, Vincent A, Dhoot GK, Newsom-Davis J. Acetylcholine receptors in human thymic myoid cells in situ: an immunohistological study. Ann Neurol. 1987 Aug;22(2):212-22.

2. Ciafaloni E, Sanders DB. Advances in myasthenia gravis. Curr Neurol Neurosci Rep. 2002 Jan; 2(1):89-95.

3. Gronseth GS, Barohn RJ. Practice parameter: thymectomy for autoimmune myasthenia gravis (an evidence-based review): report of the Quality Standards Subcommittee of the American Academy of Neurology. Neurology. 2000 Jul 12;55(1):7-15.

4. Manlulu A, Lee TW, Wan I, Law CY, Chang C, Garzon JC, et al. Video-assisted thoracic surgery thymectomy for nonthymomatous myasthenia gravis. Chest. 2005 Nov;128(5):3454-60.

5. Soleimani A, Moayyeri A, Akhondzadeh S, Sadatsafavi M, Tavakoli Shalmani H, Soltanzadeh A. Frequency of myasthenic crisis in relation to thymectomy in generalized myasthenia gravis: a 17-year experience. BMC Neurol. 2004 Sep; 11:412.

6. Tsuchida M, Yamato Y, Souma T, Yoshiya K, Watanabe T, Aoki T, et al. Efficacy and safety of extended thymectomy for elderly patients with myasthenia gravis. Ann Thorac Surg. 1999 Jun; 67(6):1563-7.

7. Romi F, Gilhus NE, Varhaug JE, Myking A, Aarli JA. Thymectomy in nonthymoma early-onset myasthenia gravis in correlation with disease severity and muscle autoantibodies. Eur Neurol. 2003; 49(4):210-7.

8. Werneck LC, Cunha FM, Scola RH. Myasthenia gravis: a retrospective study comparing thymectomy to conservative treatment. Acta Neurol Scand. 2000 Jan; 101(1):41-6.

9. Wagner AJ, Cortes RA, Strober J, Grethel EJ, Clifton MS, Harrison MR, et al. Long-term follow-up after thymectomy for myasthenia gravis: thoracoscopic vs open. J Pediatr Surg. 2006 Jan; 41(1):50-4. 
10. Chang PC, Chou SH, Kao EL, Cheng YJ, Chuang HY, Liu CK, et al. Bilateral videoassisted thoracoscopic thymectomy vs. extended transsternal thymectomy in myasthenia gravis: a prospective study. Eur Surg Res. 2005 Jul-Aug;37(4):199-203.

11. Glinjongol C, Paiboonpol S. Outcome after transsternal radical thymectomy for myasthenia gravis: 14-year review at Ratchaburi Hospital. J Med Assoc Thai. 2004 Nov;87 (11):1304-10.

12. Hatton PD, Diehl JT, Daly BD, Rheinlander HF, Johnson H, Schrader JB, et al. Transsternal radical thymectomy for myasthenia gravis: a 15-year review. Ann Thorac Surg. 1989 Jun; 47(6):838-40.

13. Bril V, Kojic J, Ilse WK, Cooper JD. Long-term clinical outcome after transcervical thymectomy for myasthenia gravis. Ann Thorac Surg. 1998 Jun; 65(6):1520-2.

14. Kawaguchi N, Kuwabara S, Nemoto Y, Fukutake T, Arimura K, Osame M, et al. Effects of thymectomy on late-onset myasthenia gravis without thymoma. Clin Neurol Neurosurg. 2007 Dec;109(10):858-61.

15. Mantegazza R, Baggi F, Bernasconi P, Antozzi C, Confalonieri P, Novellino L, et al. Videoassisted thoracoscopic extended thymectomy and extended transsternal thymectomy (T-3b) in non-thymomatous myasthenia gravis patients: remission after 6 years of follow-up. J Neurol Sci. 2003 Aug 15;212(1-2):31-6.

16. Gellert K, Bottger J, Martin T, Werner J, Mangler C, Martin H. Thoracoscopic thymectomy in the treatment concept for myasthenia gravis. Surg Technol Int. 2005;14:99-104.

17. Kawaguchi N, Kuwabara S, Nemoto Y, Fukutake T, Satomura Y, Arimura K, et al. Treatment and outcome of myasthenia gravis: retrospective multi-center analysis of 470 Japanese patients, 1999-2000. J Neurol Sci. 2004 Sep 15;224(1-2):43-7.

18. Zielinski M, Kuzdzal J, Szlubowski A, Soja J. Comparison of late results of basic transsternal and extended transsternal thymectomies in the treatment of myasthenia gravis. Ann Thorac Surg. 2004 Jul;78(1):253-8.

19. Granetzny A, Hatem A, Shalaby A, Boseila A. Manubriotomy versus median sternotomy in thymectomy for myasthenia gravis. Evaluation of the pulmonary status. Eur $\mathrm{J}$ Cardiothorac Surg. 2005 Mar;27(3):361-6.

20. Miller DK, Homan SM. Determining transition probabilities: confusion and suggestions. Med Decis Making. 1994 Jan-Mar;14(1):52-8.

21. Bonifati DM, Angelini C. Long-term cyclosporine treatment in a group of severe myasthenia gravis patients. J Neurol. 1997 Sep;244(9):542-7.

22. Shrager JB. Extended transcervical thymectomy: the ultimate minimally invasive approach. Ann Thorac Surg. 2010 Jun;89(6):S2128-34.

23. de Perrot M, Bril V, McRae K, Keshavjee S. Impact of minimally invasive trans-cervical thymectomy on outcome in patients with myasthenia gravis. Eur J Cardiothorac Surg. $2003 \mathrm{Nov} ; 24(5): 677-83$

24. Meyer DM, Herbert MA, Sobhani NC, Tavakolian P, Duncan A, Bruns M, et al. Comparative clinical outcomes of thymectomy for myasthenia gravis performed by extended transsternal and minimally invasive approaches. Ann Thorac Surg. 2009 Feb; 87(2):385-90. 